\title{
Experimental Development and Evaluation of 3 DOF Joint Unit by Wire Drive
}

\author{
○正 中川 秀夫（近畿大）吉田 晴治（近畿大）
}

\author{
Hideo NAKAGAWA, Kinki University, Seiji YOSHIDA, Kinki University
}

3 DOF (degree of freedom) joint unit that consisted of A, B and Z axis as the component of the super-multi joint manipulator, was produced, and the evaluation test was done. It is easy for this structure to control hand's position and orientation. The structure of the unit is that the end-effector is hung by three wires. 3 stepping motors wind up the wire individually. The end-effector can be made a position and orientation by controlling the wire length with the personal computer. The method of calculating the wire length by inverse kinematics was shown. The tensile test for the wire, and the examination of resolution were done. Moreover, repeatabirity was confirmed by positioning 100 times.

Key Words: Multi-joint Manipulator, 3 DOF joint unit, Wire Drive, Inverse kinematics

\section{1.はじめに}

近い将来，各方面での忘用が期待されるロボット技術の 一つに，干渉物を回避できる超多関節マニピュレータがあ る. 著者らはその開発を目指して，まずその構成要素の研 究に取り組んでいる. シリアルリンクマニピュレータの構 成要素として，関節軸が 1 点で交差する 3 自由度の関節工 ニットを用いると, どのニニットを駆動しても手先を任煮 の方向に移動できる. 寸なわち, 超圥長系の逆運動学を駆 使しなくても，手先の位置姿勢を指令方向に移動させるに は，どのコニットを駆動するのが最適であるかという選択 アルゴリズムの開発だけで行えることになる.

3 自由度を構成する軸の組み合わせは種々あるが，その 中で $\mathrm{A}-\mathrm{B}-\mathrm{Z}$ 軸構成（A，BはそれぞれX，Y軸回りの回転 軸）を採用した。直線軸 $(Z)$ を含むのは，伸縮が可能な超 多関節マニピュレータは今までになく, 広い忘用の可能性 があるからである。

また，ワイヤを用いたのは，ニニットの軽量化に大きく 寄与するためである. シリアルリンクマニピュレータにと って，リンクおよびアクチュエータの自重軽量化は必須で ある，装置の軽量化，高速化のためにワイヤを用いた例は 多く 1)2)3), 本装置もべースにアクチュエータを設置し，ユ ニットに動力伝達するワイヤ式を採用した。

以上のような検討を経て，3 自由度関節コニットを試作 し，その基㗏的な評価テストを行ったので報告する。

Table 1 Specs of 3D0F joint unit by using wire drive

\begin{tabular}{|l|l|}
\hline Angle of tilting axis $(\mathrm{A}, \mathrm{B})$ & max. $\pm 30 \mathrm{deg}$ \\
\hline Travel of Z-axis & $50 \mathrm{~mm}$ \\
\hline Drive motor torque & $12.7 \mathrm{~N} \cdot \mathrm{cm}$ \\
\hline Wire stroke & $110 \mathrm{~mm}$ \\
\hline Wire diameter & $0.53 \mathrm{~mm}$ \\
\hline Radius of wire fixture points & $75 \mathrm{~mm}$ \\
\hline Size of end-effector & $170 \times 170 \mathrm{~mm}$ \\
\hline Weight of end-effector & $1.78 \mathrm{~kg}$ \\
\hline Size of installations & $300 \times 300 \times 300 \mathrm{~mm}$ \\
\hline
\end{tabular}

\section{2. 装置の概要}

表 1 に本装置の計画仕様を示す，機構は性能評価のため の傾斜センサや変位計測のための測定スペースなどがあっ て，また部品に市販品を用いたため大きくなっている。

図 1 に本装置の構成図を示す，パソコンから回転方向指 令とパルス列がモータドライバ $(1 / 4$ 分割マイクロステッ プ機能付）に出力され，それに応じてステップ角 $1.8 \mathrm{deg}$ ユニポーラステッピングモータが回転される.モータシャ フトに取り付けられた直径 $18 \mathrm{~mm}$ のプーリによってワイヤ が巻き取られる，ワイヤにテンションを与えるため，装置 はべースプレートからの吊り下げ式としている。使用した ワイヤは, $7 \times 19$ 本の然り線ステンレスワイヤで, 直径 0.53 $\mathrm{mm}$ (実測值) である。このワイヤで半径 $75 \mathrm{~mm}$ の円周上に 等分された 3 点からエンドェフェクタを引張る。

3 つのワイヤ引張点の中心にボールスプラインシャフト を配置し， $Z$ 軸回りの回転を拘束して上下運動のみを可能 とした。 さらに，そのシャフトの先端にジンバル機構を組 込み，エンドエフェクタが回転 2 軸動作をできるようにし ている.

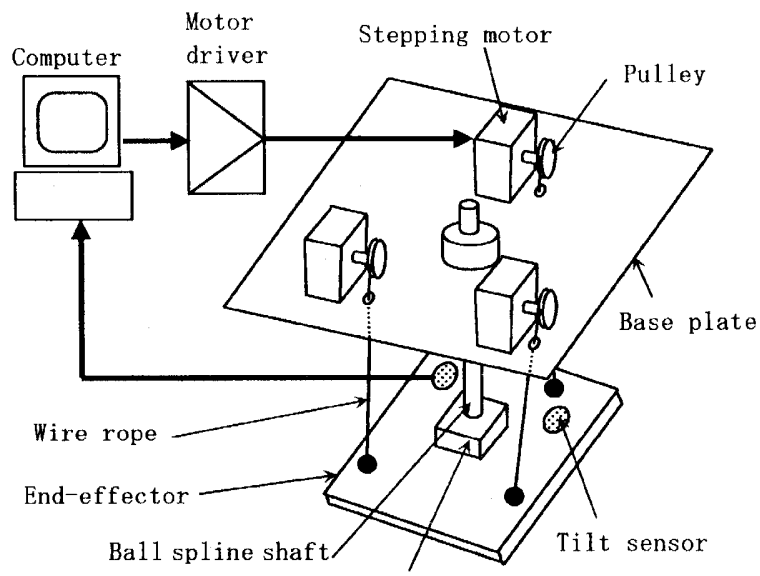

Gimbals mechanism

Fig. 1 Schematic diagram of the setup of 3DOF joint unit 


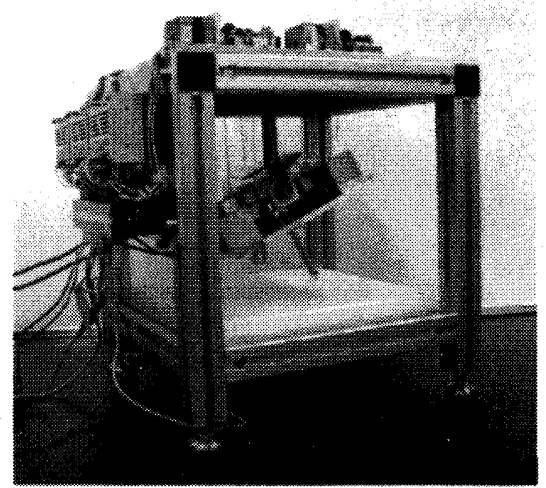

Fig. 2 Outside view of the setup

エンドエフェクタには 2 つの傾斜センサが付いており， 直交する 2 方向の傾斜角が検出できる. そのアナログ出力 が A D変換ボードを介してパソコンに取り込まれる.

なお, 図示していないが各ステッピングモータのシャフ トにはスリット付の円盤が取り付けてあり，マイクロフォ トセンサにより原点位置の検出が可能である.

装置の外観写真を図 2 に示す.

\section{3. 逆運動学}

実用上，与えられるのはエンドエフェクタの傾きではな く，そこに取り付けたハンドの座標 ${ }^{0} p(x, y, z)$ である. そこで, 基準座標系を $\Sigma 0$, エンドェフェクタ上の座標系 を $\Sigma \mathrm{A} ， \Sigma \mathrm{A}$ から法線方向にノルム $\mathrm{m}$ のベクトルを設定する （図 3). すると, 回転角 $\alpha, \beta$, および $\Sigma 0$ から $\Sigma \mathrm{A}$ までの $\mathrm{Z}$ 方向の距離 $\mathrm{h}$ は,

$$
\begin{aligned}
& \alpha=a \tan 2\left(\mp y, \pm \sqrt{m^{2}-x^{2}-y^{2}}\right) \\
& \beta=a \tan 2\left(x, \pm \sqrt{m^{2}-x^{2}}\right) \\
& h=z-\sqrt{m^{2}-x^{2}-y^{2}}
\end{aligned}
$$

と求められる。

また，位置のシフト量 $\mathrm{h}$ と回転角 $\alpha, \beta$ によって， $\Sigma \mathrm{A}$ から $\Sigma 0$ への同次変換行列 ${ }^{0} T_{\mathrm{A}}$ が求まるので, エンドェフ エクタ上のワイヤ固定点 $\mathrm{P} 1, \mathrm{P} 2, \mathrm{P} 3$ は $\Sigma 0$ で表した座標 に変換できる.よって, ワイヤの長さは, $\mathrm{P}-\mathrm{Q}$ の 2 点間の ベクトルノルムとして計算できる.

\section{4. 評価テスト}

4.1 ワイヤ引張陚铮 ワイヤを使用する際, その伸び 量が装置の位置決め精度を左右するので, まずワイヤの引 張り試験を行った．図 3 に示すように, ワイヤの耐荷重と しては $280 \mathrm{~N}$ であるが, 荷重 $50 \mathrm{~N}$ のところですべりが起こ った. 複数本の結果から，ワイヤの然りが原因と考えられ る. したがって, 繰り返し荷重を与えるとき $50 \mathrm{~N}$ 以下で使 用しなければならないが, 本装置のエンドエフェクタの重 量は $1.78 \mathrm{~kg}$ であり, 問題ないことが確認された。

4.2 分解能の検討 ステッピングモータのステップ 角は $1.8 \mathrm{deg}$ で，プーリ径から計算すると 1 ステップ 0.28 $\mathrm{mm}$ 引張られることになる. 上記の逆運動学を用いて任意の 2 位置のワイヤ長さを計算し, その差を分解能とすれば, $\mathrm{m}=120 \mathrm{~mm}$, ハンドの移動範囲 $100 \times 100 \times 50 \mathrm{~mm}$ の中で計 算したところ, 最大 $1.04 \mathrm{~mm}$ となった。 しかし, モータの

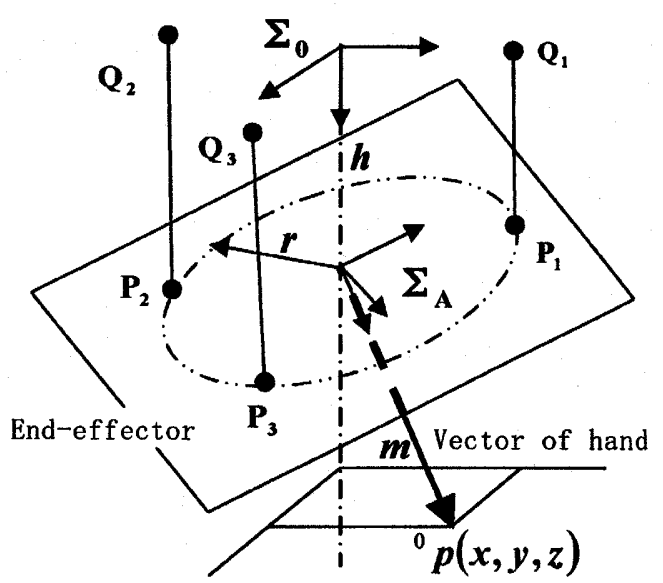

Fig. 3 Setting coordinates on the end-effector

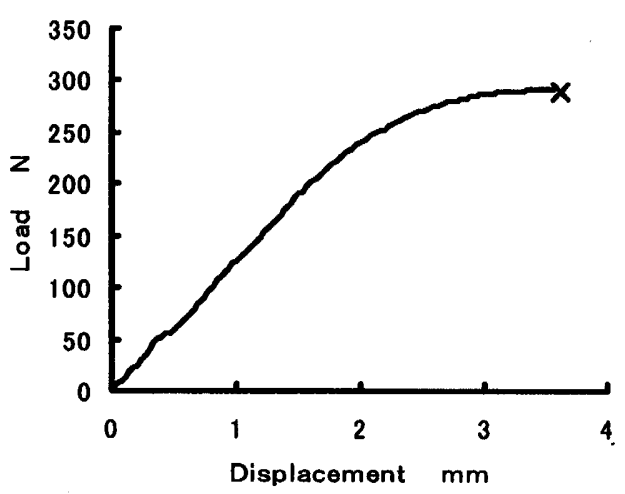

Fig. 4 Tensile test diagram for using wire rope

駆動ドライバにはマイクロステップ機能があり，これを用 いると 1/4 分割が可能で, 使用上差し支えないと考える.

4.3 練返し位置決め エンドエフェクタの下端に電 気マイクロメータを当て，1 本ずつ上下運動を 100 回繰り 返し，元の位置に戻ることを確認した．数回 $0.8 \mathrm{~mm}$ の誤差 を生じたが,プーリ上でワイヤが交差したものであり，巻き 取り位置を一定にすることで解消された。

\section{5.まとめ}

超多関節マニピュレータを構成する 3 自由度関節ユニッ トを試作し，評価テストを行った。実用化する上では，よ り軽量でコンパクト化する必要があるが, 当初計画した機 能を確認した．今後, 自重に対する考慮, ワイヤテンション の一定化，ブレーキシステムの導入など，実用的な対策に ついて検討していく.

\section{参若文献}

1) 広瀬, 馬 : ワイヤチ涉駆動型多関節マニピュレータの開 発, 計測自動制御学会論文集, 26, 11（1990）1291.

2）大涱, 新井, 浅間：3本のワイヤを有する 7 自由度クレ ーンの開発 (第 1 報), 精密工学会誌, 59, 5 (1993) 767 .

3)川村，催，田中，木野：パラレルワイヤ駆動方式を用い た超高速ロボット FALCON の開発, 日本ロボット学会誌, 15, 1 (1997) 82. 